\title{
Augustin Nguh
}

\section{PUTTING THE CART BEFORE THE HORSE: HOW THE EU-AFRICA COOPERATION ON MIGRATION HAS FAILED AND WHAT TO DO ABOUT IT}

\begin{abstract}
With the ongoing Covid19 pandemic, the adoption of policies and measures restricting mobility can be observed all over the world. This paper notes that the relationship between migration and development is circular and complex, embracing both negative and positive impacts. It explores the enactment of migration management policies that favour development at home (Africa) to prevent migration, with the trade-offs of security concerns. The paper finds these policies and measures to have failed and proposes what can be done to ensure a better Africa-European Union (EU) migration management.

KEYWORDS: Migration, migration management, European Union, Africa, Covid19 pandemic

JEL: F22, F50, K38
\end{abstract}

\section{INTRODUCTION}

Migration management has earned great scholarly and political interest while remaining a theoretically contested notion (Ansem de Vries \& Guild, 2019). There is no universally accepted definition of migration management. For the purpose of this research, the definition advanced by Ann Beduschi is adopted. Beduschi holds migration management to be "different strategies, policies, processes and procedures, negotiated and adopted by relevant actors at the international level to provide a framework to manage migratory flows in an orderly and predictable manner" (Beduschi, 2020:3). However, as Castles notes, "the political will and assumed capacity to manage migratory flows is often contradicted by reality, as migration is a complex phenomenon that cannot be easily 'managed" (Castles, 2004b:214). This has not hindered states, international organisations and even intergovernmental/supranational organisations such as the European Union (EU) and the African Union (AU) from trying to manage 'large movements of people' through the 'implementation of planned and well-managed migration policies' (e.g., Valletta Action Plan, 2015). 
The migration crisis that began in late 2014 and reached its zenith in 2015 indicates such 'planned and well-managed migration policies' have registered limited success. This is because migration governance "juxtaposes two potentially competing visions: regulating forms of mobility and controlling irregular migration" (Zanker, 2019). Regarding the former, migration is accepted as an instrument for development. Policies in this direction seek to facilitate mobility (Zanker, 2019). However, with the ongoing Covid19 pandemic, the adoption of policies and measures restricting mobility has been observed all over the world. In the current pandemic situation, the return to the status quo ante on mobility remains a thing of speculation. It is worthy of note that the relationship between migration and development is circular and complex, embracing both negative and positive impacts (Clemens, 2014, cited in Zanker, 2019). Development is also considered a territorialized process (disconnected from globalization), leading to the enactment of migration policies that prefers development at home to 'prevent' migration (Nijenhuis \& Leung, 2017). Consequently, to policymakers, development is a trade-off to security concerns (Zanker, 2019).

Regarding irregular migration, the militarization of EU borders since 2015 is evident. Based on the alleged fear that immigration may threaten public health and order, and/or the cultural identity of the recipient countries, migrants have increasingly been portrayed as a securitized object (i.e., a security threat from which Europe must shield itself by any means necessary) (Szalai, 2015). For example, in 2015, a former Polish Prime Minister alleged migrants have brought diseases like cholera and dysentery in Europe, as well as "all sorts of parasites and protozoa, which, while not dangerous in the organism of these people, could be dangerous here" (Cienski, 201G). The outbreak of the Covid19 pandemic reinforced this rhetoric. For example, such rhetoric was re-echoed by the Hungarian Prime Minister who in response to a radio interview question on why universities had been closed, but not schools, said "it is because there are lots of foreigners there. Our experience has taught us that primarily foreigners brought in the disease and that it is spreading among foreigners" ("Hungary's Orban blames foreigners", 2020). While it is a fact that the first cases of Covid19 brought to Hungary came with returning Iranian students, one should not lose sight of the fact that Mr. Orban is often the victim of the liberal media as he is usually presented as the villain, whatever he says or does.

Adopting the securitized approach to migration colligates the freedom of movement (which until the outbreak of the Covid19 was possible) within Europe with stronger borders ("Fortress Europe") and an 'externalization' of migration controls (Andersson, 201G; Bourbeau, 2015). Externalization of migration sees borders not as 'the territorial limit of the [supra-] state but [as] the management practices directed at "where the migrant is"' (Cobarrubias et al., 2014:19). This is evident concerning undocumented migration, whereby Europe out-sources 
border work to follow migrants upstream along their routes. Italy's 2017 controversial agreement with the Libyan coast guard reflects this practice of externalization. Since the collapse of the Ghaddafi regime, Italy has been providing technical support to the Libyan coastguard as well as information on migrant vessels (Bathke, 2017). The goal of externalization is to stop migrants before they approach Europe. Given that most illegal migrants come from sub-Saharan Africa and transit through countries like Sudan, Mali, Niger, Libya, and Tunisia to EU member states, the EU and its member states have found it increasingly imperative to cooperate with Africa on migration issues.

Migration research within and with Africa is limited, geographically and thematically, focusing only on one region or type of migration category (e. g., forced versus 'voluntary' migration) (Brachet, 2010). According to Flahaux and de Haas (201G) whilst the literature on migration patterns in Africa repeatedly highlight that most African migration is intra-African, the fact that those moving out of Africa do not only move to Europe but also to the Gulf countries and the Americas (Blackwell \& de Haas, 2007) is not reflected in the literature on the topic (see Schoumaker et al., 2015; Sander \& Maimbo, 2003). A research gap, therefore, exists in migration governance between Europe and Africa. Some policy frameworks exist and acknowledge the need for Africa-EU migration to be transnationally governed. Nevertheless, gaps exist between rhetoric and implemented policies (Zanker, 2019). These gaps, which Czaika and de Haas (2013) termed the 'implementation gap', have not been addressed in considerable depth in terms of the EU-Africa regional cooperation on migration. Considering that the need for transnational governance of Africa-EU migration has been acknowledged and policies adopted, yet gaps exist in their implementation, this research is interested in the question:

- How has the EU-Africa regional cooperation on migration failed and what can be done about it?

To answer this question, this paper will consider the rhetoric contained in the various policy instruments and the implementation of these instruments from 2000 to the present. The year 2000 is selected as the point of departure for this research because it was in 2000 that the first Africa-EU summit took place, under the aegis of the EU and the Organisation of African Unity (OAU), now African Union (AU). The rest of the paper is structured as follows:

- Section 2 explores the EU-Africa regional migration policy instruments, paying close attention to their rhetoric and goals.

- Section 3 explores the implementation of these policy instruments and highlights how these instruments have failed to achieve their intended goals. 
- Section 4 offers a general conclusion and highlights what can be done to ensure better cooperation on migration between the EU and Africa.

\section{MIGRATION MANAGEMENT IN EU-AFRICA RELATIONS}

In 2005, 13 migrants were killed, and hundreds wounded while trying to climb over the fenced border into the Spanish enclaves of Ceuta and Melilla which sits on the northern shores of Morocco's Mediterranean coast. These events signalled the need for a 'global strategic approach to managing migration' (European Commission, 2005). The outcome was the adoption of the Global Approach to Migration (GAM) in 2005 which was clarified in 2011 to include "Mobility" and it became the Global Approach to Migration and Mobility (GAMM). This policy document provides an overarching framework for the EU's external migration and asylum policy and pursues four goals of equal importance:

- managing legal migration.

- preventing and combating irregular migration.

- maximizing the development impact of migration.

- promoting international protection.

The GAMM lays the foundation for a new framework for EU migration and asylum policy. This shift in policy was reflected in the EU's call for striking a balance between the various aspects of migration and was formally introduced in a 2008 communication titled "Strengthening the Global Approach to Migration: Increasing Coordination, Coherence and Synergies".

To implement the 'global approach', mobility partnerships were introduced. Under these partnerships, the EU embarked on developing an innovative way to addressing migration issues in all their complexity'. The first of these partnerships (the EU-Africa Partnership for Migration, Mobility, and Employment) was launched in Lisbon (2007), together with an action plan and framework for dialogue and cooperation with the African Union as its privileged contact point. Amongst the priority actions touted by the European Council was the adoption of a Strategy for Africa, which clearly showed the aim to strengthen migration cooperation with African countries.

Migration has no doubt been one of the AU and EU's areas of collaboration. The two regions and their representative collective organs have jointly adopted several policy frameworks categorized as soft laws, which shall be explored under this section of the paper. This section shall be divided into two sub-sections: The first explores the policy documents jointly adopted, while the second offers an analysis of the policy documents. 


\subsection{Policy Instruments Adopted}

These instruments shall be grouped and analyzed under two time-frames: Pre2014 instruments (1) and post-2014 instruments (2).

\subsubsection{Pre-2014 instruments}

The instruments adopted during this phase include the Cairo Action Plan (2000), Cotonou Agreement (2000), The Rabat Process (200G), the Tripoli Process (200G), and the Khartoum Process (2014). While it is tempting to engage in a content description of all the listed instruments, such endeavour shall be avoided. Rather, the fine line that connects all these documents shall be made visible.

Though adopted at different periods, these instruments have one thing in common: they seek to provide a solution to one of the challenges facing both Africa and Europe - Migration. As contained in the Cairo Action Plan (2000), the EU laid down several priority action areas, mainly consisting of supporting African countries in ensuring free intra-African mobility of labour and migration and collaborating in addressing the root causes of migration and asylum-seeking in source, transit, and recipient countries. Further, the action plan discusses the reciprocal integration of migrants, migrant rights, and readmission agreements between European and African countries (United Nations Conference on Trade And Development, 2000).

In 2000, another agreement was signed in Cotonou between the EU and the African, Caribbean, and Pacific Group of States (ACP). Known as the Cotonou Agreement and set to expire in September 2020, this agreement governed cooperation between the parties in the domain of development, politics, economy, and trade. Article 13, which was the most contentious of the Agreement, contained a migration clause. Article 13 defines the parameters of the EU-ACP dialogue on migration and is the result of a difficult compromise between the parties' different views and interests on migration. As highlighted by Vanheukelom et al (200G:G), "On the EU side, member state; under domestic pressure to reduce irregular migration from Africa; strongly endorsed the integration of a readmission clause into the Agreement. On the ACP side, securing the protection of the rights of migrants' residing and working in the EU was the most relevant concern". Negotiations for EU-Africa relations post-Cotonou is ongoing.

From 2005, several EU-African declarations, partnerships and other cooperative frameworks have been created to establish a mutually beneficial 'management' of African migration. Emphasis is placed here on 'migration management' and 'partnership', given that they have been adopted for the distinct goal of clarifying that the EU's intention no longer rested on one-sided control and prevention (Hansen \& Jonsson, 2011). In this case, migration management to enhance Africa's development is paramount, and must be realized through such 
measures as codes of conduct to prevent brain drain, facilitate remittances, assist the return of highly skilled migrants, encourage the role of diasporas and migrant communities in the development of Africa, and to promote democratic governance and human rights.

Such and other objectives unfolded in the wake of the Euro-Africa Ministerial Conference on Migration and Development, held in Rabat in 200G (the Rabat Process). This conference was convened in part by the aforementioned Ceuta and Melilla incidents. An even greater motive for the conference consisted of the significantly increased entry of African migrants to the EU in 2005 and 200G. Both the Spanish government and the EU Commission claimed that long term solutions could not be based on security measures alone, but also required measures reducing inequalities between the North and the South (Mead, 2005). In line with this, the conference in Rabat adopted both the security and development dimensions of migration on its agenda.

In 2018, during the Euro-African Ministerial Conference held in Marrakesh, the need to encourage and strengthen pathways to regular migration was recognized by the participants. They also recognized the need to promote the mobility of certain categories of travellers such as businessmen and businesswomen, young professionals, or researchers between European and North, West, and Central African countries. (European Commission, 2019). The promotion of regular migration and mobility especially of young people and women, between Europe and North, West and Central Africa, and within these regions was equally decided upon.

One should note that though the security and development dimensions of migration appeared in the Rabat process, the security approach got the better side of it (Noll, 200G:1). The very first concrete measure that emerged from the 200G Rabat conference was the setting up of a common EU coast guard tasked with patrolling the waters between the African mainland and the Canary Islands.

Since Rabat, there have been several high-level EU-African meetings and agreements on migration, adopting the same rhetoric of 'partnership of equals' 'win-win dynamics,' "security and African development". For example, the 200G Tripoli Process or the Joint Africa-EU Declaration on migration and development was coated as a "partnership" aimed at addressing "migration and its root causes through broader development and poverty reduction strategies". Similarly, the 2014 EU-Horn of Africa Initiative (the Khartoum Process) also referred to a "partnership to...promote sustainable development to address the root causes of irregular migration; establish a regional framework for return, including voluntary, and reintegration; and assist countries in establishing and managing established centres and providing access to asylum processes". Both policy instruments include clauses highlighting development benefits to African countries if they cooperated with the EU on migration issues. 


\subsubsection{Post-2014 Instrument}

The main instrument here is the Valletta Summit on Migration Action Plan adopted in 2015. This instrument introduced a trust fund - the European Union Emergency Trust Fund for Africa (EUTFA) - with an initial budget of EUR 1.8 billion, key to the issue of the relationship between migration and development. Though these relationships are complex, EU policies have in the past presented them as superficial, entirely based on countering the root causes of irregular migration. This approach is repeated in the Valletta Action Plan wherein both parties (the EU and Africa) reaffirmed their commitment to "address the root causes of migration; to advance legal migration and mobility possibilities; to strengthen the fight against irregular migration; to prevent and fight migrant smuggling, eradicating trafficking in human beings; and to strengthen international protection and step-up assistance" (European Council, 2015:17).

Pastore (201G) notes that one clear objective of this document is to strengthen the external projection of European control and protection policies to keep many migrants and asylum seekers as possible in Africa.

\subsection{Analysis}

EU policy makers acknowledge most migration take place within the continent (Zanker, 2019). However, EU-Africa migration management policy documents still focus on irregular migration towards Europe (Zanker, 2019), given the preponderance of the terms 'illegal' and 'irregular' migrants and the insertion of a South-North dimension in the said instruments. Put simply, the documents indicate the EU perceives migration from Africa as a security issue. The result has been among others, EU-Africa border militarization which has been greatly criticized within the academic, civil society and political milieu. For example, the former AU Chairperson - Nkosazana Dlamini Zuma -stated that 'the problem that we are facing today is in part because some countries in Europe have taken a fortress approach...' and that '... the African Union expresses concern about the militarization of its shores and airspace' (African Union, 2015). The EU's focus on migration as a security issue underlines the belief that migration may infringe on public order and consequently state sovereignty. According to DeVargas and Donzelli there is a tendency in the EU to conflate crime and terrorism with migratory movement (DeVargas \& Donzelli, 2014). Inserting the words 'fighting', 'combatting', 'illegal', with respect to migration in the various policy documents, creates a 'linguistic action' or a 'speech act' and convey a sense of 'urgency' and 'priority'(Weaver \& Buzan, 1993:3). Furthermore, the language of these documents does not merely describe, but also mobilize certain meanings, thus creating a 'domain of insecurity', which is further tackled through specific security practices. 
Development issues have equally been at the forefront of EU-Africa cooperation. Development had from the beginning been firmly placed on the agenda by African partner states, while the EU and its member states had clung to security. However, a change in perspective can be observed over the years: the 'root causes approach' initially provided the main frame for understanding the link between migration and development. Irregular migration was perceived as negative phenomenon to be curbed by development cooperation. Over the last decade, the analysis has come to be much more differentiated and the potential impact of migration on development has taken a front seat. The change in perspective has led to a more holistic view of migration and equally offered a common frame to discuss legal migration, irregular migration, and labour migration from an overarching perspective. For example, discussions during the Rabat Process started with debate on irregular migration particularly between Spain and Morocco, but it soon became clear that a security-driven approach could neither help both parties understand the dynamics of irregular migration nor contribute to sustainable solutions. It was realized that if well-managed migration could be a be a positive element for the economies of both origins and destination countries and the migrants, if linked to sustainable development.

The policy documents also presented legal migration as alternative to irregular migration and as something positive for the African continent. The decision to migrate irregularly/illegally is sometimes due to very restrictive legal channels for migration, or the lack of information about such legal channels. Hence, opening legal channels for migration, providing better information on legal migration possibilities and on the risks of irregular migration would be crucial to managing migration flows. Nevertheless, legal migration remains a bone of contention between the EU and Africa. Here, the different views between the EU and AU or African states are visible. While the EU favours restricting mobility to the African continent and returning irregular migrants back to Africa, African states are more interested in opening channels for legal migration to Europe. The strong rhetoric of legal migration in the policy instruments tends to be vague, often referring to educational programs. This vagueness and limited avenue for legal migration only indicate the disagreement between the parties as to where legal migration channels should lead to. In a way, it also highlights the asymmetric power dynamics between the two parties, with the EU being the stronger power, dictating the terms to the weaker African side.

One would agree with Zanker (2019), and Nijenhuis \& Leung (2017) that migration has become increasingly accepted as a tool for development and that development may be considered as a territorialized process leading to the enactment of migration policies that favour development at home to 'prevent' migration. Put simply, the EU-Africa policy frameworks adopt an approach aimed at curbing migration from Africa by first of all supporting development activities 
and poverty reduction strategies in Africa so that African youths can stay in Africa and not seek for opportunities in Europe. If that fails, then as a last resort, encourage legal migration (to Europe) through various schemes such as the liberalization of visa regimes for certain categories of people (students, businessmen and businesswomen, etc). This approach goes in tandem with a securitized approach (fortification of EU borders, externalization of migration control, etc.).

In line with these policy frameworks, during the 2018 High-Level Forum AfricaEurope held in Vienna, the former President of the EU Commission - Jean-Claude Juncker - reiterated Europe's ambition for a true and fair partnership among equals with Africa. He admitted Europe's future is tied with Africa's and proposed a new Africa-Europe Alliance for Sustainable Investment and Jobs intending to attract both European and African investment and create 10 million jobs in Africa over the next five years (European Commission, 2018).

Steps have already been taken to implement these policy initiatives. It is therefore imperative to examine whether these steps have yielded fruits.

\section{THE IMPLEMENTATION OF THE POLICY INSTRUMENTS AND HOW THEY HAVE FAILED}

To achieve its goal of stopping irregular migration from Africa, the EU created the EUTFA. As of 31 December 2018, resources allocated to the EUTFA amounted to about EUR 4.G billion coming from the European Development Fund and member states and donors (European Commission, 2018). Of this sum, around EUR 490 million is pledged by donors (Switzerland and Norway) and member states, many of whom are struggling to finance the inflow of migrants/refugees in their home countries (European Commission, 2018).

The EUTFA operates along four strategic axes which are set out in the Strategic Orientation Document adopted in November 2015 by the Strategic Board of the EUTFA. These axes are:

- Greater economic and employment opportunities.

- Strengthening resilience of communities.

- Improved migration management.

- Improved governance and conflict prevention.

It is along these axes that the implementation of the EU-Africa instruments shall be explored and later analysed.

\subsubsection{Greater economic and employment opportunities}

In 2018, the European Commission accelerated the implementation of actions aimed at reducing motivations for migrating illegally by creating employment and economic activities in countries of origin and transit. In the Sahel and Lake Chad 
region, tailor-made responses have been offered to specific challenges addressing constraints on the labour market including employability of youth and economic development in production sectors. By the end of December 2018, 92 actions amounting to 1.7 billion euros have been approved for this region. These actions support 24,211 beneficiaries to increase their skills and employability through Technical and Vocational Education and Training (TVET) actions (European Commission, 2018:21). Based on the EUTFA 2018 annual report, previously approved actions have made considerable progress to support job creation for young people through 'quick win' actions in origin and transit areas of Guinea and Niger. About 10,852 jobs have been created in the region (European Commission, 2018:21). It should be noted that the report is silent on what constitutes 'quick win' actions, the nature of the 10,852 jobs created and the estimated salaries or wages these jobs will bring to the employed. In other words, information on job and income stability is absent. Therefore, it goes to reason that if the jobs are not permanent and/or the income/wage derived from said jobs are low concerning the individuals' family size and needs, the said individuals will be left with no choice than to try migrating up north to Europe in search of better opportunities.

\subsubsection{Strengthening the resilience of communities}

The EUTFA 2018 annual report indicated that in the Sahel and Lake Chad region, actions have been taken to address food insecurity and malnutrition whilst improving access to basic services, promoting public services and long term issues such as social cohesion and natural resources management (European Commission, 2018:25). Resilience actions apply "an agile and conflict-sensitive approach, capable of adapting to a rapidly changing context", (European Commission, 2018:25). Examples of resilience action cited in the report include the improvement, through diagnosis, monitoring and infrastructure maintenance of water, hygiene, and sanitation services in Far North Cameroon, which will benefit 30,000 households (European Commission, 2018:25).

The report also states that in the Horn of Africa, the EUTFA has delivered more than two million basic services in the region (European Commission, 2018:32). However, the report is silent as to what is considered a 'basic service'. Programs undertaken in this region include among others, the IMPACT program in South Sudan which is helping to keep children in school by providing more than 28,000 primary teachers in almost 2,500 schools with salary supplements that allow the teachers to stay in service and increase their attendance (European Commission, 2018:32). The report also claims that actions targeting the improvement of living conditions, household resilience and economic opportunities for refugees and locals have also been undertaken in Ethiopia. It should be noted that such a claim is very vague, and it camouflages that no outcome can be reported. 
Given that migration patterns in the North of Africa are complex, it is asserted that the EUTFA continues to ensure protection and assistance to those in need. Notable action undertaken includes the provision of essential healthcare, critical goods, and a safe environment for the most vulnerable persons. Activities aimed at enhancing sustainable livelihoods for displaced persons and their host communities and social cohesion have also been carried out (European Commission, 2018: 37). However, the EUTFA does not define what it meant by critical goods, neither does it provide its readers with the type of activities it carried out aimed at enhancing the sustainable livelihoods of the targeted beneficiaries. This makes it difficult for one to assess the success or failures of the measures implemented.

\subsubsection{Improved migration management}

The 2018 EUTFA report contends that in the Sahel and Lake Chad region, continuous support is offered to the UN High Commissioner for Refugees (UNHCR) Evacuation Transit Mechanism (ETM). This has enabled the protection, evacuation and resettlement of refugees stranded in Libya. Support has also been extended to the EU-IOM Joint Initiative providing protection, voluntary return assistance to migrants in transit and reintegration in the countries of origin (European Commission, 2018:25). For example, between September 2017 and December 2018, 2,202 persons have been evacuated from Libya to Niger in the ETM frame, 3,719 individuals have been proposed for resettlement from Libya and Niger to 12 countries, while 1,598 individuals qualified as a refugee has departed for resettlement from Niger and Libya to Belgium, Canada, Finland, France, Germany, the Netherlands, Sweden, Switzerland, the United Kingdom and the United States (European Commission, 2018:25).

According to the Commission report, in the Horn of Africa, the EUTFA has continued to work with African partner countries to develop national and regional approaches to address migration challenges, help protect vulnerable migrants and reintegrate those who wished to return (European Commission, 2018:32). This is done through the Better Migration Management program, run in partnership with the German Federal Ministry for Economic Development and Cooperation. More than 10,000 people have received voluntary assistance, and many more have been given additional help to reintegrate, in the form of immediate assistance on arrival, psycho-social support, skills training, education, among others. These returnees come from Libya and other countries in the Horn of Africa.

\subsubsection{Improved governance and conflict prevention}

In the Sahel and Lake Chad region, the EUTFA in 2018 supported regional cooperation through organisations such as G5 Sahel to foster long-term stability. The G5 Sahel is an institutional framework for the coordination of regional 
cooperation in development policies and security matters in West Africa. Its member states are Burkina Faso, Chad, Mali, Mauritania, and Niger. With financial support from the EUTFA, the Sahel Security School, which is a part of the G5 Sahel was set up. This school's ambition is regional: promoting dialogue between law enforcement agencies and their communities as well as developing a common culture about crisis and threats (terrorism, radicalization, and organized crime) (European Commission, 2018:2G). Still, in 2018, six new actions were approved totalling EUR 89 million. New activities included quick impact security measures in Mali, migration and border management in Niger, increasing security in border areas in Chad as well as support the fight against migrant smuggling and human trafficking in Cape Verde, Burkina Faso and Guinea Bissau (European Commission, 2018:2G-27).

In the Horn of Africa, a regional action worth EUR 5 million was approved in 2017 to better equip national agencies to disrupt migrant smuggling and human trafficking networks in the region through the efficient use of financial investigation and anti-money laundering tools (European Commission, 2018:33). Over 8,700 people from both state and non-state organisations have been trained on border management, conflict prevention, countering violent extremism and protecting civilians using a human rights approach (European Commission, 2018:34).

The above paragraphs show that goals 1 and 2 of the EUTFA emphasize addressing the root causes of irregular migration (through jobs and resilience), while goal 4 focuses on addressing causes of displacement (through governance and conflict prevention). Goal 3 is the only goal dedicated to migration management. As Zanker notes, none of these goals presumes a positive migrationfor-development nexus, nor do they focus on legal forms of migration to Europe (Zanker, 2017:31). In analyzing projects aimed at addressing Goal 3, Zanker found that at least five mentioned variation on 'promoting strengthened migration management' at both national and local levels (Zanker, 2017:32). More specific targets include encouraging diaspora investment, capacity building for managing migrant influxes, and the development, harmonization and implementation of migration policies ranging from human trafficking to labour laws. Four projects were directed at fighting organized crime and traffic in humans while 7 projects focused on awareness and sensitization campaigns to deter people from leaving in the first place (Zanker, 2017:33), as well as projects aimed at setting up research observatories, monitoring and evaluating projects and enhancing data collection (13 projects). 11 projects focus on improving conditions for voluntary return and reintegration. Though a few of the sensitization campaigns refer to legal migration, the overall emphasis is on (voluntary) returning migrants and securing borders. 


\subsection{The failures of the Policy Instruments}

According to Welz (2015), "despite numerous summits and meetings, the achievements of the EU-Africa instruments on migration have been few and far between, depending on the political commitment of individual states". Welz's assertion has been resounded by scholars like Reitano (201G) who contended that the Rabat Process has produced few substantial results despite running for more than a decade.

Zanker (2017) posits that the implementation of the EU-Africa instruments has been varied. The Khartoum Process is reputed to be even more difficult to implement considering the lack of mobility available there. This is also compounded by the fact that the Sudanese and Eritrean citizens are not allowed to leave their country without permission and the lack of trust between the countries participating (Reitano, 201G). While supporting Zanker's assertion on the varied nature of implementing the instruments, this paper contends the implementation of the policy instruments have not curbed the inflow of irregular migrants into the EU (1), neither do they offer international protection to migrants (2).

\subsubsection{Failure to stop irregular migration}

Since 2015, migrant boats continue to cross into EU waters. The lucky ones manage to make it to EU shores. Some are not so fortunate. Either they are intercepted and returned to Libya, or their lifeless bodies wash up on EU shores or are lost at sea. This indicates not only a failure to curb irregular migration from Africa, but also the acuteness of the situation. The number of boat arrivals at the shores of the EU is a testament to this acuteness. According to the International Organisation for Migration (IOM) from January to November 2019, 89,997 migrants/refugees entered Europe through the sea. This represents an 11 per cent decline from 101,185 that arrived during the same period, the previous year. The death record for that year stood at 1090, representing about a 52 per cent decline from the previous year's figures for the same period (2098 individuals) (IOM, 2019). From January 2020 to April 2020, 1G,724 migrants entered Europe by sea, indicating a $1 \mathrm{G}$ per cent increase during the same period a year earlier (IOM, 2020). When Covid19 started, states around the world took measures such as instituting a general lockdown to cushion their citizens from the devastating health impact of this pandemic. As a result, the number of irregular entries by boat into the EU dwindled. However, the gradual/slight lifting of restrictions that happened in summer 2020 brought in fresh attempts at illegally entering the EU either with the help of smugglers or with the assistance of states like Turkey who have weaponized migration. 


\subsubsection{Failure to offer international protection to irregular migrants}

The EU-Africa instruments do not offer international protection to irregular migrants. The EU adopts a human rights language to "sell" its Trust Fund programme and is quite careful to paint the issues it seeks to address as complex (Chandler, 2018). However, in practice, the human rights of those trying to enter the EU illegally are overridden by the zeal to preserve EU security. The EU's border control measures "have tightened the noose around the North and Horn of Africa, making dangerous journeys even more perilous" (Reitano, 201G). Millions of euros have been poured into renovating detention facilities and the training of guards in Libya. Yet, these centres are still in a horrible state. The EU has equally allocated over 100 million euros to the IOM to return people to their homes through country partnership (Hayden, 2019). The UNHCR also received some funds to evacuate some people to Niger for asylum screening and resettlement. As Chandler argues, "removing people from horrific detention centres is a humanitarian imperative but, regrettably, it does not address the underlying issue, i.e., the EU's continued support for the Libyan coast guard has forced vulnerable people directly back into the same detention centres where they are bought and sold" (Chandler, 2018).

The EU border control projects have equally been widely critiqued. The EU border control projects have been held to contradict not only European foreign policy and diplomatic actions but also basic European human rights standards (Castillejo, 201G).

Moreover, the use of the words "to prevent and fight migrant smuggling", "eradicating trafficking in human beings;" and "to strengthen international protection and step up assistance" in the policy instruments seemed to ignore the fact that smuggling and trafficking thrive with the blessing of the certain North African and Horn of Africa governments officials, police and border guards (Davy, 2017; Frouws \& Horwood, 2017). An investigation by Refugees Deeply (an independent digital media project dedicated to covering refugee issues around the world) documented the involvement of Sudan's high-level government officials in trafficking (Suleiman \& van Dijken, 2018). This confirms a claim made by the US Department of State that Sudan does not meet the minimum criteria for the elimination of trafficking (US Department of State, 2018).

The above analysis highlights an implementation gap between rhetoric and practice in EU-Africa migration policy as asserted by Czaika and de Haas' (2013). The EU's migration policy emphasizes tackling the root causes of irregular migration through projects targeting the creation of jobs and building resilience in communities across the 3 priority regions in Africa. However, as Frasca notes, "EU migration policies are too often victims of eurocentrism, posing unrealistic goals and expectations towards cooperation with Africa" (Frasca, 2019:8). It is a 
fact that African migration is largely intra-African, with only a tiny percentage of Africans migrating to Europe. Moreover, the EU is not the only player in Africa. China, Russia, and the US are making are interested in the continent. For this reason, the EU should consider reassigning due weight to cooperation with Africa. Cooperation with Africa is bigger than migration cooperation and attempts to 'stop' migration from Africa have proven to be ineffective.

In addition, the various policy instruments and the measures taken to implement the EU's goal of stopping migration to the EU from Africa, reveal how the EU in a practical sense believes it can generate a win-win dynamic between its security-oriented approach (fight against illegal migration) on one hand, and (as Hansen and Jonsson (2011)) puts it its neoliberal fight for growth and competitiveness' on the other hand.

\section{WHAT TO DO ABOUT IT?}

Migration is an important area in EU-Africa cooperation. Yet, the EU and Africa have fundamentally different views on migration management. As demonstrated in this paper, the EU and its member states prioritizing prevention and return while African states focus more on remittances and legal opportunities for migration. As equally highlighted in the first two sections of this paper, Europe's approach does not acknowledge these differing interests and seeks to impose its own agendas in ways that threaten to undermine Africa's ambitions.

The EUTFA initiative has caused significant controversy: the EUTFA is based on the inaccurate hypothesis that development assistance can prevent migration. It diverts aid to migration goals, and its projects do not often fulfil development principles such as transparency, ownership, and alignment. In consideration of the failures of the policy instruments and measures to stop migration, it can be asserted that the EU has to change its approach to migration management and save itself the embarrassment of continuously putting the cart before the horse. To rectify the failures of the EU's current approach to migration management:

- The EU must recognize that Europe will need African migration in the future. Put simply, the EU must accept that demographic and socioeconomic differences/realities mean that Africans with the will and/or resources will migrate towards Europe, and Europe will need African labour. The EU must work with Africa as equal partners to explore how best to promote movements that support Africa's economic growth and allows both continents to reap the benefits of safe and orderly migration. This should include different types of migration opportunities:- circular migration, research and education, business and work- strengthening remittances and skills transfer to Africa. The EU should relax its visa regime and embrace circular migration. 
- The EU needs to address its 'solidarity deficit' with its members on migration and asylum issues. This requires honesty concerning conflicting interests between member states and working towards effective common systems that can effectively manage fluctuating migratory flow and integrate incoming migrants (both irregular and regular). It will also require that EU leaders shift their current political discourse to build acceptance of migrants and migration.

- The EU needs to switch from trying to address the 'root causes' of migration with short term emergency funds. There is considerable difficulty tackling the 'root causes' of involuntary movements through development cooperation and other measures. As Angenendt, Martin-Shields and Schraven (2017) note, given the international community's limited success in addressing fragile statehood and the growing number of violent conflicts, more honesty is needed in the effective discussions.

\section{REFERENCES}

Ansems de Vries, L. - Guild, S. (2019). Seeking refuge in Europe: Spaces of transit and the violence of migration management. In: Journal of Ethnic and Migration Studies, 2019, 45, 12.

African Union (2015). Statement of H.E. Dr Nkosazana Dlamini Zuma Chairperson of the African Union Commission on the Occasion of the Valletta Summit. African Union. Retrieved from https://au.int/fr/node/25444

Andersson, R. (201G). Europe's failed 'fight' against irregular immigration: Ethnographic notes on a counterproductive industry. Journal of Ethnic and Migration Studies, 42, (7), 1055-1075.

Angenendt, S., Martin-Shields, C. \& Schraven, B. (2017). More Development-More Migration? The "Migration Hump" and Its Significance for Development Policy Cooperation with Sub-Saharan Africa. SWP Comment 40/2017, Berlin, Stiftung Wissenschaft und Politik.

Bakewell, O. \& de Haas, H. (2007). African Migrations: continuities, discontinuities and recent transformations, in L. de Haan, U. Engel, \& P. Chabal (eds.), African Alternatives (pp.95-118). Leiden, Brill.

Bathke, B. (2019). When helping hurts - Libya's controversial coast guard, Europe's go-to partner to stem migration. Infomigrants. 24 July 2019. Retrieved from https://www.infomigrants.net/en/post/1819G/when-helping-hurts-libya-scontroversial-coast-guard-europe-s-go-to-partner-to-stem-migration 
Bourbeau, P. (2015). Migration, resilience, and security: Responses to new inflows of asylum seekers and migrants. Journal of Ethnic and Migration Studies, 41 (12),1958-1977.

Brachet, J. (2010). Blinded by security: Reflections on the hardening of migratory policies in Central Sahara. IMI Working Paper Series, 2G.

Castles, S. (2004). Why migration policies fail. Ethnic and Racial Studies, 27 (2), 205227.

Castillejo, C. (201G). The European Union Trust Fund for Africa: a glimpse of the future for EU development cooperation. Bonn, German Development Institute. Retrieved from http://www.die-gdi.de/discussion-paper/article/theeuropean-union-trust-fund-for-africa-a-glimpse-of-the-future-for-eudevelopment-cooperation/

Chandler, C. (2018). How far will the EU go to seal its borders?. EUROZINE,. Retrieved from https://www.eurozine.com/far-will-eu-go-seal-borders/\#footnote-14 Cienski, J. (201G). 'Migrants carry 'parasites and protozoa,' warns Polish opposition leader'. POLITICO. Retrieved from https://www.politico.eu/article/migrantsasylum-poland-kaczynski-election/

Cobarrubias, S., Casas, M., Garelli, G., Heller, C., Pezzani, L., Pickles, J., and Tazzioli, M. (2014). Externalization (new keywords: Migration and borders). Cultural Studies,29, (1),19-23.

Czaika, M. \& De Haas, H. (2013). The Effectiveness of Immigration Policies. Population and Development Review, 39 (3), 487-508.

Davy, D. (2017). Unpacking the Myths: Human Smuggling from and within the Horn of Africa, Danish Refugee Council, RMM Briefing Paper, G December.

DeVargas, M. \& Donzelli, S. (2014). 'Sub-Saharan Migrants' Masculinities: An Intersectional Analysis of Media Representation during the Libyan War 2011' In Migration, Gender and Social Justice, Springer, pp. 241-2G3.

European Commission (2018). The Marrakesh Political Declaration. Retrieved from https://ec.europa.eu/homeaffairs/sites/homeaffairs/files/20180503 declaration-and-action-planmarrakesh en.pdf

European Council (2015). Valletta Summit, 11-12 November: Action Plan. Retrieved from https://www.consilium.europa.eu/media/21839/action plan en.pdf 
Flahaux, M. L, \& de Haas, H. (201G). African migration: Trends, patterns and drivers, Comparative Migration Studies, Vol. 4. Retrieved fromhttps://doi.org/10.118G/s40878-015-0015-G

Frasca, E. (2019). European Migration Policies with African Countries: Insights into the current year, CeDIR Working Papers No.2019/03.

Frouws, B. \& Horwoods, C. (2017). Smuggled South: An updated overview of mixed migration from the Horn of Africa to southern Africa with a specific focus on protectin risks, human smuggling and trafficking. Danish Refugee Council, RMMs Briefing Paper 3.

"Hungary's Orban blames foreigners, migration for Coronavirus spread", France 24. 2020. Retrieved from https://www.france24.com/en/20200313-hungary-spm-orban-blames-foreign-students-migration-for-coronavirus-spread

IOM (2019). Mediterranean migrant arrivals reach 88,997 in 2019; Deaths reach 1,090. Press Releases. Geneva.

IOM (2020). Mediterranean migrant arrivals reach 1G,724 in 2020; Deaths reach 25G. Press Releases, Geneva.

Nijenhuis, G., \& Leung, M. (2017). Rethinking migration in the 2030 agenda: Towards a de-territorialized conceptualization of development Forum for Development Studies, 44, (1), 51-G8.

Pastore, F. (201G). "Migration and the future of EU-Africa relations". Aspenia, 7172, May 201G, 209-219.

Pelz, D. (2019). 'EU must rethink its approach to migration', DW, available at https://www.dw.com/en/eu-must-rethink-its-approach-to-migration/a$\underline{47324133}$

Reitano, T. (201G). The Khartoum Process: A sustainable response to human smuggling and trafficking? Institute for Security Studies, Policy Brief 93.

Sander, C. \& Maimbo, S. M. (2003). Migrant labour remittances in Africa: Reducing obstacles to developmental contributions. Africa Regional Working Paper Series. Washington DC: World Bank.

Shoumaker, B., Flahaux, M.L, Schans, D., Beauchemin, C., Mazzucato, V. \& Sahko, P. (2015). Changing patterns of African migration: A comparative analysis. In C. Beauchemin (Ed.), Migration between Africa and Europe: Trends, factors, and effects. New York: Springer-Verlag \& INED Population Studies Series.

United States Department of State (2018). 2018 Trafficking in Persons Report:

Sudan. 28 June 2018. Retrieved

fromhttps://www.refworld.org/docid/5b3e0a714.html 
United Nations Conference on Trade And Development (2018). Economic Development for Africa report 2018: Migration for structural transformation. UNCTAD.

Vanheukelom, J; Mackie, J., \& Bossuyt, J. (200G). "Political Dimensions: Introductory Note" ECDPM seminar: The Cotonou Partnership Agreement: What role in a changing world? Maastricht, 18-19 December 200G.

Weaver, 0., and Buzan, B. (1993). Identity, migration, and the new security agenda in Europe. London: Pinter.

Welz, M. (2015). The Roles of the African Union and its Member States in managing migration across the Mediterranean, In IPPOLITO, Francesca et al. (ed), Migration in the Mediterranean: Mechanisms of international cooperation/, Cambridge, Cambridge University Press, pp. 94-114.

Zanker, F. (2017). The Politics of the EU and African Migration Governance: From Rhetoric to Practice. ABI Working Paper No. 5, Freiburg, Germany.

Zanker, F. (2019). Managing or restricting movement? Divergent approaches of African and European migration governance. Comparative Migration Studies, 7 (17). https://doi.org/10.118G/s40878-019-0115-9

Augustin Nguh, LL.M, M.A.

$\mathrm{PhD}$ Candidate (International Economic Relations and Management)

Fh-Burgenland-Eisenstadt/University of Economics in Bratislava

\section{DISCLOSURE STATEMENT}

This work was made possible with a scholarship from the Institute of Advanced Studies, Koszeg (iASK). 
